\title{
AUTONOMOUS REPLICATION OF PLASMIDS IN MUCOR TRANSFORMANTS
}

by

\author{
ROBYN VAN HEESWIJCK
}

\author{
Chr. Hansens Laboratorium A/S, \\ Sankt Annæ Plads 3, DK-1250 Copenhagen K \\ and \\ Department of Physiology, Carisberg Laboratory, \\ Gamle Carlsbergvej 10, DK-2500 Copenhagen Valby
}

Keywords: Plasmid, Mucor ars sequence, filamentous fungi, eukaryote

Evidence is presented for the autonomous replication of recombinant plasmids in Mucor circinelloides $\mathrm{Leu}^{+}$ transformants. Plasmids consisting of a unique fragment of Mucor DNA inserted into YRp17 or pBR322 (i) give a high frequency of transformation (up to $7800 \mathrm{Leu}^{+}$transformants per $\mu \mathrm{g}$ DNA), (ii) are mitotically unstable, (iii) can be reisolated in an unmodified form from uncut transformant DNA, and (iv) are present as discrete extrachromosomal DNA molecules (as detected by Southern hybridisation).

No integration of the transforming DNA can be detected in Mucor transformants containing free plasmid molecules. This excludes the possibility that free plasmids are simply excision products resulting from a reversal of the integration process.

Sub-cloning of the recombinant plasmids and analysis of subsequent Leu transformants show that autonomous replication is independent of the vector sequences and locates a Mucor ars within a $4.4 \mathrm{~kb}$ Pstl fragment of the insert DNA.

\section{INTRODUCTION}

Mucor is a filamentous fungus of Class Zygomycetes which is of biological and industrial interest because of the production of a variety of extracellular enzymes $(1,2,25,33,34)$ and the ability of some species to undergo a morphogenetic change from hyphal to budding yeastlike growth in response to various environmental stimuli (5). The absence of a utilisable sexual recombination system for genetic analysis and manipulation $(13,31)$ made it desirable to develop a transformation system and introduce recombinant DNA technology into the study of these organisms. The transformation of $\mathrm{M}$. circinelloides with hybrid plasmid DNA was reported in a previous publication (16). Cloning of a $\mathrm{Leu}^{+}$gene by direct complementation was made possible by the high frequency of transformation and the ability to recover plasmids from the transformant DNA. These properties of the transformation suggested that the hybrid plasmids might replicate autonomously within the Mucor cells, however, the data available did not enable differentiation between this and integration of the transforming DNA into the Mucor genome.

Abbreviations: ars = autonomous replication sequence; $\mathrm{CsCl}=$ cesium chloride; $\mathrm{EtBr}=$ ethidium bromide; $\mathrm{kb}=$ kilobase pairs; $\mathrm{RNase} \mathrm{A}=$ ribonuclease $\mathrm{A} ; \mathrm{SSC}=$ sodium chloride, sodium citrate buffer. 
In transformation of the yeast Saccharomyces cerevisiae, vectors can become integrated into the host genome or be maintained as extrachromosomal elements $(12,39)$. The sequences responsible for autonomous replication of the extrachromosomal plasmids can be derived from endogenous S.cerevisiae plasmid $(2 \mu \mathrm{m}$ plasmid) or from specific chromosomal fragments (termed $A R S$ for autonomous replication sequences).

The transformation of filamentous fungi has generally been shown to result from the integration of vector sequences into the host genome (e.g. Neurospora crassa $(8,11)$, Aspergillus nidulans $(3,40,43)$, Aspergillus niger $(9,21)$, Podospora anserina $(6,7)$ and Cochliobolus heterostrophus (42)). Putative ars's have been isolated from the DNA of N. crassa, A. nidulans, Cephalosporium acremonium and Phanerochaete chryosporium but none have yet been shown to provide autonomous plasmid replication in these fungi themselves $(4,8,10,26,27$, $32,37,40,41)$. There is some discussion as to whether the coenocytic nature of fungal hyphae results in conditions favouring selection of integrated sequences and the rapid loss of inherently unstable extrachromosomal elements $(8,26)$, however, reports have been made of the autonomous replication of plasmids within $\mathrm{P}$. anserina (36) and $\mathrm{N}$. crassa $(14,22,26,38)$.

In this communication evidence is presented for the autonomous replication in Mucor circinelloides of hybrid plasmids constructed from a fragment of Mucor DNA inserted in YRp17 or pBR322. Sub-cloning of these plasmids and analysis of subsequent transformants show that the property of autonomous replication is independent of the vector sequences and locates a Mucor ars within a $4.4 \mathrm{~kb}$ PstI fragment of the insert DNA.

\section{MATERIALS AND METHODS}

\subsection{Strains}

A leucine auxotroph of $M$. circinelloides $f$. lusitanicus CBS 277.49 (syn. M. racemosus ATCC 1216b (30)) designated strain R7B (29) was used as recipient in all Mucor transformation experiments. The spontaneous reversion frequency of this strain to $\mathrm{Leu}^{+}$is $<1.7 \times 10^{-8}$.
Escherichia coli HB101 was used for isolation of plasmid DNA and as the recipient strain in bacterial transformation experiments.

Media and growth conditions were as previously described (16).

\subsection{Chemicals}

Restriction enzymes, calf alkaline phosphatase, T4 DNA ligase and E. coli DNA polymerase I were obtained from Boehringer Mannheim (FRG). All enzymes were used according to the conditions specified by the manufacturers. Novozym 234 was a gift from Novo Industries (Denmark), RNase A was from Sigma (USA), nitrocellulose filters (BA 85) were from Schleicher \& Schuell (FRG), and $\boldsymbol{\alpha}^{32} \mathrm{P}$ $\operatorname{dATP}(>600 \mathrm{Ci} / \mathrm{mmol})$ was from New England Nuclear (USA).

\subsection{Plasmids}

Plasmid pMCL1302 (Figure 1) was selected from a Mucor gene bank constructed in the yeast-E.coli shuttle vector YRp17 by complementation of $\mathrm{M}$. circinelloides R7B Leu followed by back-transformation of E.coli to ampicillin resistance (16). Plasmid pMCL002 (Figure 1) was constructed by insertion of the $6.6 \mathrm{~kb}$ EcoRI - SalI and $4.5 \mathrm{~kb}$ EcoRI fragments isolated from pMCL1302 into SalI - EcoRI digested pBR322. Orientation of the latter fragment was checked by mapping of restriction sites.

\subsection{Transformation procedures}

E. coli HB101 was transformed to ampicillin resistance after induction of cell competence by the $\mathrm{CaCl}_{2}$ method (23).

Protoplasts of Mucor were obtained by treatment of germinating sporangiospores with Novozym 234 and streptozyme (15). Approximately $10^{6}-10^{7}$ viable protoplasts were transformed with $0.25-5 \mu \mathrm{g}$ DNA as previously described (16). Transformation frequencies of up to 7800 per $\mu \mathrm{g}$ DNA, or $3 \times 10^{-3}$ per viable cell were obtained with either plasmid pMCL1 302 or pMCLO02. 

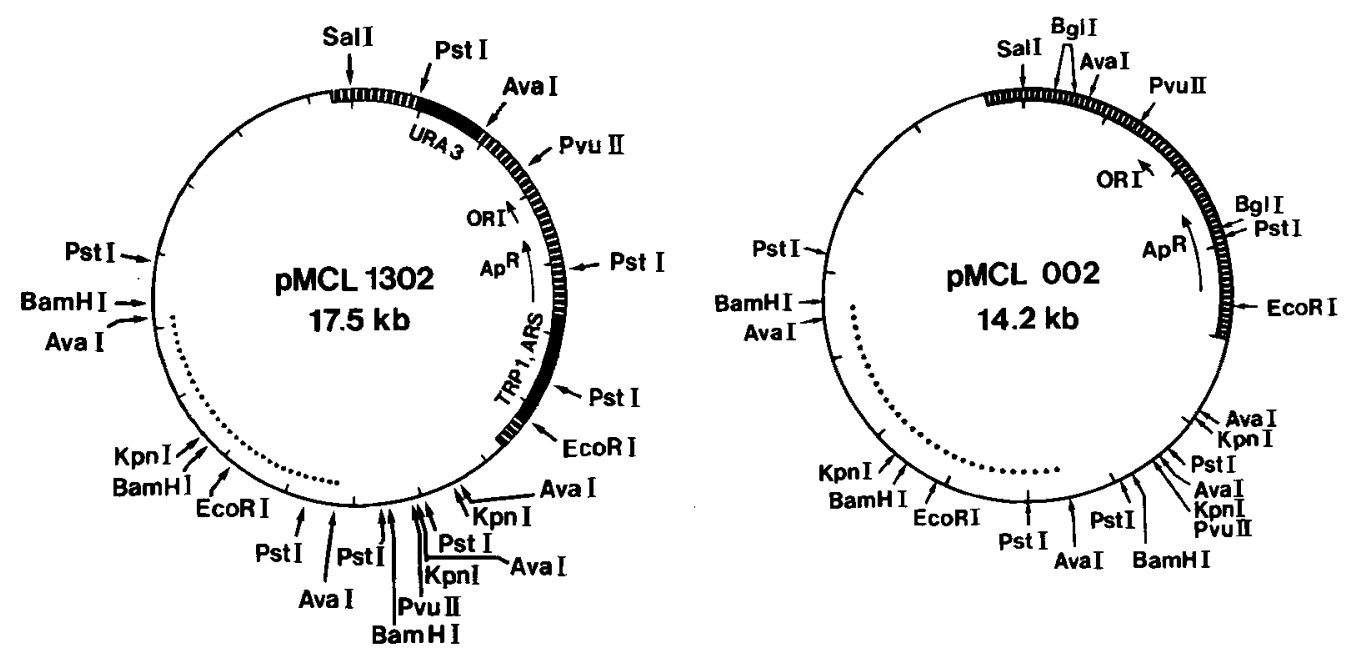

Figure 1. Restriction maps of plasmids pMCL1302 and pMCL002. Plasmids are not drawn to the same scale. Location of restriction sites for AvaI, BamHI, EcoRI, KpnI, PstI, PvuII and SalI are shown on both plasmids and for BglI for plasmid pMCL002 only. The thick lines are the vectors YRpI 7 and pBR322, respectively: the thick black lines represent sequences derived from $S$. cerevisiae, the thick barred lines represent sequences derived from E. coli. The thin line is the Mucor DNA insert. The dotted line indicates the $3.9 \mathrm{~kb}$ Aval fragment used as the radioactive probe in Figures 2 , and 5 . Subcloning experiments and DNA sequencing data locate the Leu ${ }^{+}$gene within this fragment.

\subsection{Isolation of DNA}

Plasmid DNA was isolated from E. coli cultures by the alkaline lysis method of IsHHoROwicz and Burke (19). DNA from small scale Mucor cultures was prepared by the method of YELTON et al. (43) with some modifications (16). After RNase A treatment the DNA was extracted once with phenol, then ethanol precipitated, or purified further by centrifugation in $\mathrm{CsCl}$ gradients of average density 1.55 $\mathrm{g} \cdot \mathrm{ml}^{-1}$ or $1.66 \mathrm{~g} \cdot \mathrm{ml}^{-1}$ in the presence or absence of $\operatorname{EtBr}\left(6 Q 0 \mu \mathrm{g} \cdot \mathrm{ml}^{-1}\right)$, respectively. In the presence of EtBr only a single fluorescent band could be detected by UV illumination and this was withdrawn using a needle and syringe by puncturing the side of the tube. In the absence of $\mathrm{EtBr}$ the tube was punctured in the bottom and drop-wise fractions were collected. These fractions were assayed for DNA content by spotting aliquots onto agarose gels containing ethidium bromide $\left(0.5 \mu \mathrm{g} \cdot \mathrm{ml}^{-1}\right)$ and the appropriate fractions pooled and ethanol precipitated. In all cases, final DNA yields were estimated visually after electrophoresis in $1 \%(\mathrm{w} / \mathrm{v})$ agarose gels in the presence of ethidium bromide. Since no low molecular weight bands were ever seen upon electrophoresis, the DNA estimations reflect the amount of high molecular weight genomic DNA in the preparations. The average yield obtained was $50 \mu \mathrm{g}$ DNA per $100 \mathrm{ml}$ culture.

\subsection{Hybridisation analyses}

In order to detect the presence of free plasmid molecules in Mucor transformants, the DNA isolated therefrom was electrophoretically separated on $0.4 \%(\mathrm{w} / \mathrm{v})$ agarose gels, with or without prior treatment with restriction endonucleases, then transferred to nitrocellulose filters according to the method of Southern (35).

Labelling of plasmid DNA or fragments derived therefrom with $\alpha^{32} \mathrm{P}-\mathrm{dATP}$ was performed by nick translation according to RIGBY et al. (28). Specific radioactivities of $2 \cdot 10^{7}-2 \cdot 10^{8}$ cpm per $\mu \mathrm{g}$ DNA were obtained. Hybridisation of ${ }^{32} \mathrm{P}$-labelled DNA to the DNA immobilised on nitrocellulose was performed at $68^{\circ} \mathrm{C}$ in $6 \times \mathrm{SSC}$ according to MANIATIS et al. (24) after which 
filters were washed in $0.1 \times \mathrm{SSC}$ at the same temperature. Autoradiography was carried out using Kodak X-Omat RP X-ray film with Kodak X-Omatic regular intensifying screens at $-80^{\circ} \mathrm{C}$.

\section{RESULTS}

\subsection{Recovery of plasmids from uncut Mucor DNA}

M. circinelloides R7B was transformed to $\mathrm{Leu}^{+}$with plasmids pMCL1302 or pMCL002, then the DNA was isolated as described in section 2.5, and used to transform E. coli HB101 to $a m p^{r}$. The yield of $a m p^{r}$ transformants obtained was 0-4 per $\mu \mathrm{g}$ DNA, with up to a total of 200 from the DNA extracted from $100 \mathrm{ml}$ of culture.

Restriction fragment analysis of plasmids isolated from $52 \mathrm{amp}^{\mathrm{r}}$ colonies derived from 8 different Mucor DNA preparations revealed no differences from the original transforming plasmids.

Only one flourescent band could be seen in $\mathrm{CsCl} / \mathrm{EtBr}$ gradients of DNA isolated from $\mathrm{Mu}-$ cor transformants, however, the expected position of any covalently closed plasmid circles could be determined by running parallel gradients containing $200 \mathrm{ng}$ of the transforming plasmid (pMCL1302 or pMCL002) isolated from E. coli. After ethanol precipitation of fractions extracted from this region and resuspension in $100 \mu \mathrm{l}$ TE buffer $\mathrm{pH} 8.0,1.0 \mu \mathrm{l}$ aliquots were used in the transformation of $E$. coli HB101 giving rise to 1-7 amp colonies per aliquot, with a total of up to $700 \mathrm{amp}^{\mathrm{r}}$ colonies obtained from the DNA isolated from a $100 \mathrm{ml}$ culture.

The number of $a m p^{r}$ colonies obtained does not accurately reflect the abundance of plasmid within Mucor transformants since preparations of Mucor DNA are found to inhibit the transformation of E. coli by plasmid DNA, the degree of inhibition varying with the method of DNA purification (16).

\subsection{Detection of free plasmid molecules by Southern hybridisation analysis}

When the total DNA isolated from Mucor transformants is electrophoresed in a $0.4 \%(w / v)$

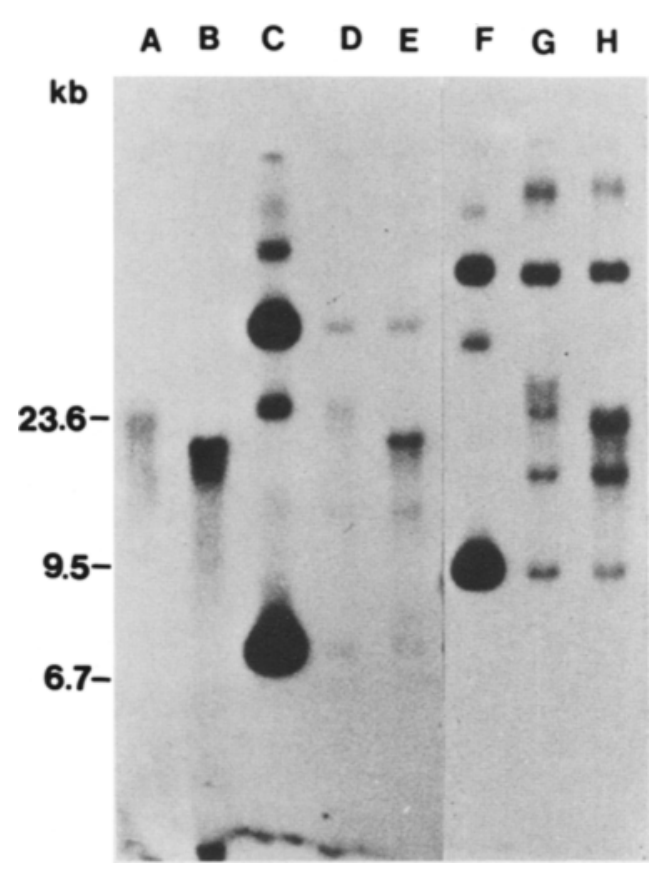

Figure 2. Southern hybridisation of the ${ }^{32}$ P-labelled 3.9 $\mathrm{kb}$ Aval fragment of Mucor DNA (Figure 1) to untransformed and transformed $M$. circinelloides DNA. Lanes contain DNA from the following sources: $A$ and B, recipient strain R7B ( $150 \mathrm{ng}$ ); C, pMCL002 (0.5 ng); $D$ and $E$, strain R7B transformed with pMCL002, R7B-002-1 (100 ng); F, pMCL1302 (0.5 ng); G and H, strain R7B transformed with pMCL1302, R7B-1302-1 $(200 \mathrm{ng})$. Lanes A, D, and G contain DNA isolated as described in section 2.5 and purified by phenol extraction. Lanes $\mathrm{B}, \mathrm{E}$ and $\mathrm{H}$ contain DNA which has been purified further by $\mathrm{CsCl}$ gradient centrifugation (in the absence of $\mathrm{EtBr}$ ) prior to complete digestion with $\mathrm{Hpal}$. Lanes $C$ and $F$ contain undigested plasmid isolated from E. coli. After electrophoresis in a $0.4 \%(w / v)$ agarose gel in the presence of $\operatorname{EtBr}\left(0.5 \mu \mathrm{g} \cdot \mathrm{ml}^{-1}\right)$ the DNA was transferred to a nitrocellulose filter and hybridised to the radioactive probe as described in section 2.6. All samples are run on the same gel but lanes A - E were exposed for 24 hours, while lanes $F$ $-\mathrm{H}$ were exposed for 12 hours.

agarose gel, blotted and hybridised to the ${ }^{32} \mathrm{P}$-labelled $3.9 \mathrm{~kb}$ Aval fragment common to both pMCL1302 and pMCL002 (Figure 1) distinct bands of hybridisation can be seen in the undigested DNA of the transformants (Figure 2, 
lanes $D$ and $G$ ) but not in that of the Leu' strain R7B (Figure 2, lane A). The difference in the electrophoretic mobilities of the bands in lanes $D$ and $G$ are due to the difference in the size of the transforming plasmids. In either case, the lowest band can be seen to comigrate with covalently closed plasmid circles isolated from E. cotti.

The restriction endonuclease $\mathrm{HpaI}$ cleaves within the genomic DNA of strain R7B, producing a fragment of $20 \mathrm{~kb}$ which hybridises to the $3.9 \mathrm{~kb}$ Aval probe (Figure 2, lane B). HpaI does not cleave within pMCL1302 nor pMCL002, therefore hybridisation bands representing free plasmid molecules should remain unaltered by digestion of transformant DNA with this enzyme. Transformation by homologous integration of pMCL1 302 or pMCL002 should result in an increase in the size of the $20 \mathrm{~kb}$ genomic HpaI fragment by $17.5 \mathrm{~kb}$ or $14.2 \mathrm{~kb}$ (or multiples thereof), respectively. Heterologous integration should result in appearance of one or more novel Hpal fragments hybridising to the $3.9 \mathrm{~kb}$ AvaI probe. Figure 2, lanes $\mathrm{E}$ and $\mathrm{H}$ show that $\mathrm{HpaI}$ digestion of transformant DNA results in appearance of only the one genomic HpaI fragment equivalent in size to that of the recipient strain R7B (lane B). The hybridisation patterns remain otherwise unaltered from those of the undigested DNA. This confirms that the discrete bands of hybridisation seen in the undigested DNA represent free plasmid molecules, and suggests that no integration of the transforming plasmid sequences has occurred. A comparison of hybridisation intensities indicates the plasmids are present in low copy number and enables an estimate of 2-4 copies per haploid genome to be made. "Dot-blots" of other transformants derived from the same plasmids confirm the low copy number but show there is some variation (2-4 fold) in the amount of plasmid present in different transformants at the time of harvest for DNA isolation (results not shown).

\subsection{Autonomous replication is independent of vector sequences}

Plasmid pMCL1302 (Figure 1) contains the sequences denoted $A R S$ and $O R I$ which are responsible for maintenance of the plasmid as an autonomously replicating unit in Saccharomyces cerevisiae and Escherichia coli, respectively. As shown above, plasmid pMCL002, which is devoid of all yeast sequences present in pMCL1302 still exists as free plasmid within Mucor transformants (Figure 2).

Digestion of pMCL002 with Bgll results in cleavage at three positions within the pBR322 sequence, but leaves the insert of Mucor DNA intact. The largest of the restriction fragments $(12.2 \mathrm{~kb})$ thus contains the entire Mucor DNA insert plus $1.8 \mathrm{~kb}$ of pBR322, and is missing the E. coli $O R I$ plus approximately $1.0 \mathrm{~kb}$ and 1.3 $\mathrm{kb}$ of pBR322 DNA on either side of this region. Due to the degeneracy of the restriction site sequence of Bgll the 3' overhang ends of this fragment are not fully complementary, with one out of the three base pairs mismatched. The fragment was isolated by agarose gel electrophoresis, treated with T4-DNA ligase and the ligation mix used directly in the transformation of $\mathrm{M}$. circinelloides R7B to $\mathrm{Leu}^{+}$. DNA was isolated from four transformants and analysed by Southern hybridisation to ${ }^{32} \mathrm{P}$-labelled $\mathrm{pM}$ CL002 (Figure 3). Three of these transformants gave the pattern shown for R7B-009-5 (lanes $F$ and $G$ ). Distinct bands of hybridisation are detected in the uncut DNA (lane F) indicating the presence of free plasmid molecules. Digestion with AvaI results in a pattern of hybridisation (lane $G$ ) consistent with the presence of a plasmid composed of the $12.2 \mathrm{~kb}$ BgII fragment of pMCL002 within the transformants. Replacement of the 4.1 and $4.7 \mathrm{~kb}$ Aval fragments of pMCL002 by a single $6.5 \mathrm{~kb}$ fragment confirms absence of the E. coli ORI region. Further deletion of sequences within this region appears to have occurred in the plasmid present in transformant R7B-009-3 (lane E) where two Aval fragments of 1.8 and $2.0 \mathrm{~kb}$ are found instead of the $6.5 \mathrm{~kb}$ fragment (presence of the mismatch in the ends of the Bgll fragment may have provided a structure sensitive to nuclease digestion). Free plasmid molecules are still detected in the uncut DNA of this transformant (lane D).

Upon sub-cloning the Mucor DNA insert of pMCL1302, the $4.4 \mathrm{~kb}$ PstI fragment was found sufficient for high-frequency transformation of 


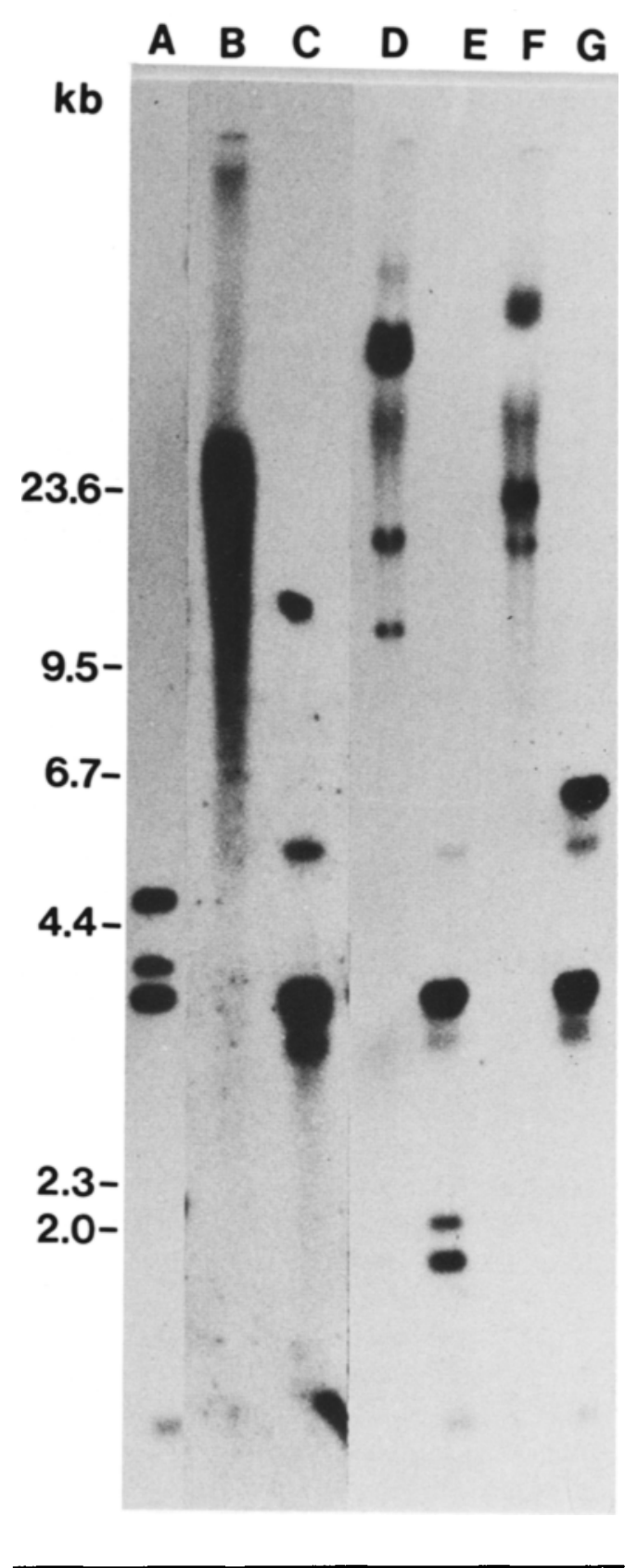

M. circinelloides R7B to $\mathrm{Leu}^{+}$when ligated into the PstI site of pBR322 (plasmid pMCL006, Figure 4). Free plasmid molecules can be detected in the uncut DNA of all four pMCL006 transformants so far analysed, as illustrated for transformant R7B-006-8 in Figure 5, lane I.
Figure 3. Southern hybridisation of ${ }^{32} \mathrm{P}$-labelled $\mathrm{pM}$ CLO02 to untransformed and transformed $\mathrm{M}$. circinelloides DNA. Lanes contain DNA from the following sources: A, pMCL002 (0.5 ng); B and C, recipient strain R7B (500 ng); D - G, strain R7B transformed with the ligation mix containing the $12.2 \mathrm{~kb}$ Bgll fragment of pMCL002, D and E: transformant R7B009-3 (500 ng), Fand G: transformant R7B-009-5 (500 ng). Mucor DNA was isolated as described in section 2.5 and purified by $\mathrm{CsCl}$ gradient centrifugation (in the absence of EtBr). DNA in lanes $B, D$, and $F$ is undigested, while that in lanes $A, C, E$, and $G$ has been digested to completion with Aval. After electrophoresis in a $0.4 \%(\mathrm{w} / \mathrm{v})$ agarose gel in the presence of $\operatorname{EtBr}(0.5$ $\mu \mathrm{g} \cdot \mathrm{ml}^{-1}$ ) the DNA was transferred to nitrocellulose filters and hybridised to the radioactive probe as described in section 2.6. All samples were run on the same gel and exposed for 24 hours except for lanes B and $C$ which were run on a seperate gel but hybridised in the same solution, and exposed for 48 hours.

When the $4.4 \mathrm{~kb}$ PstI fragment alone was isolated, self-ligated and the ligation mixture used to transform strain $\mathrm{R} 7 \mathrm{~B}$, $\mathrm{Leu}^{+}$colonies were obtained whose DNA gave hybridisation patterns again indicative of the presence of free plasmid molecules (see Figure 5 for transformant R7B4.4P-1 which is representative for all 6 transformants analysed). The discrete bands seen in the uncut DNA (lane F) remain unaltered in mobility after digestion with PvuII (lane $\mathrm{H}$ ) which cuts

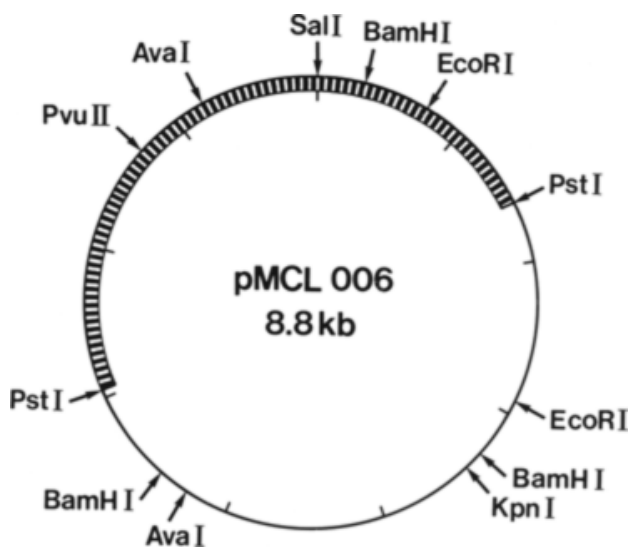

Figure 4. Restriction map of pMCL006 which consists of the $4.4 \mathrm{~kb}$ PstI fragment of pMCL002 inserted into the PstI site of pBR322. Legend is as for Figure 1. 


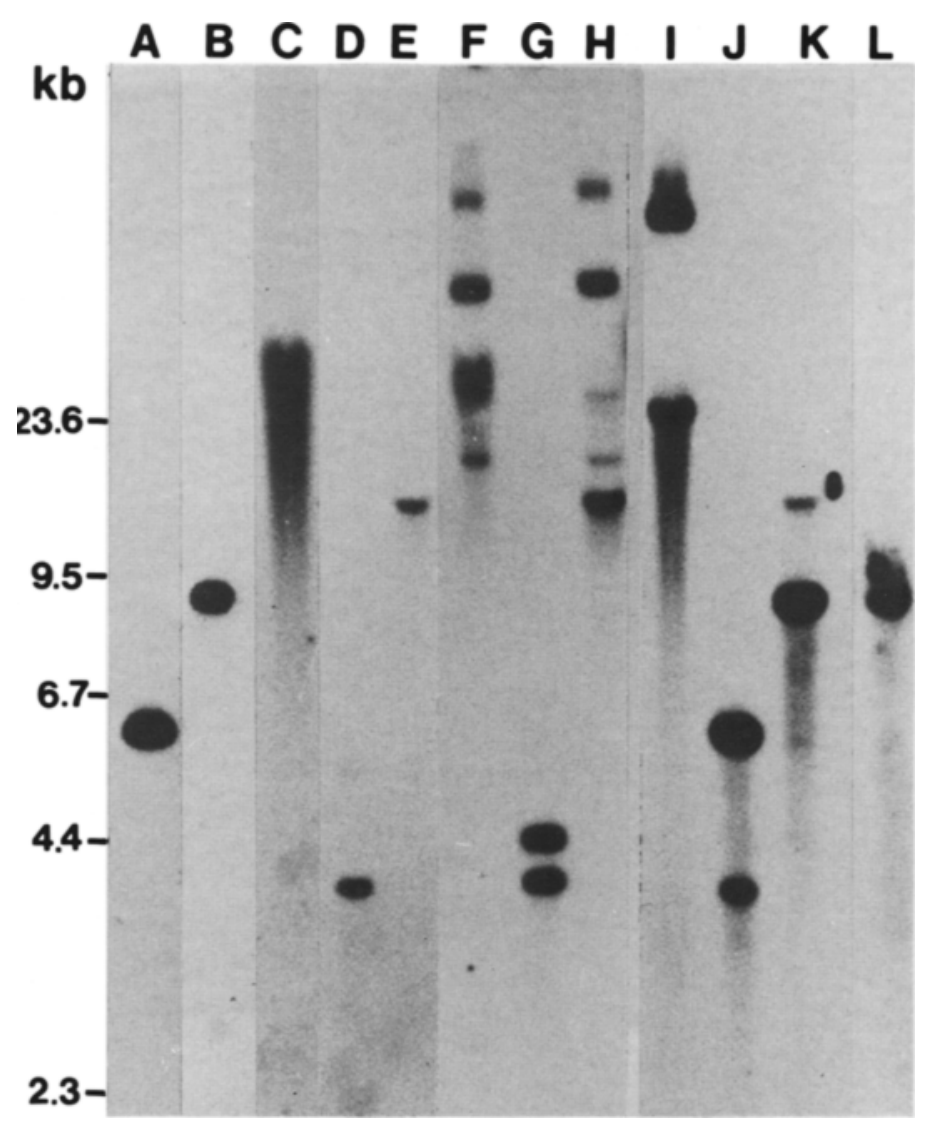

Figure 5. So: thern hybridisation of untransformed and transformed $\mathrm{M}$. circinelloides DNA to ${ }^{32} \mathrm{P}-$ labelled probes consisting of the $3.9 \mathrm{~kb}$ AvaI fragment of pMCL002 (lanes A-K) or plasmid pBR322 (lane L). Lanes contain DNA from the following sources: A and B, pMCL006 (0.5 ng); C-E, recipient strain R7B (500 ng); F-H, strain R7B transformed with the ligation mix containing the $4.4 \mathrm{~kb}$ Pstl fragment of pMCL002, R7B-4.4P-1 (500 ng); I-L, strain R7B transformed with pMCL006, R7B-006-8 (500 ng). Mucor DNA was isolated as described in section 2.5 and purified by $\mathrm{CsCl}$ gradient centrifugation (in the absence of $\mathrm{EtBr}$ ). DNA in lanes $\mathrm{C}, \mathrm{F}$, and $\mathrm{I}$ is undigested, while that in lanes $A, D, G$, and $J$ is digested to completion with AvaI, and that in lanes B, E, H, K, and L is digested to completion with PvuII. After electrophoresis in a $0.4 \%(\mathrm{w} / \mathrm{v})$ agarose gel in the presence of $\operatorname{EtBr}\left(0.5 \mu \mathrm{g} \cdot \mathrm{ml}^{-1}\right)$ the DNA was transferred to a nitrocellulose filter and hybridised to the radioactive probe as described in section 2.6. Autoradiograms were exposed for 24-72 hours.

within the genomic DNA (lane E) but not within the $4.4 \mathrm{~kb}$ PstI fragment. No hybridisation was detected when ${ }^{32} \mathrm{P}$-labelled pBR322 was used as the probe confirming the absence of any vector sequences within these transformants (results not shown). Digestion with Aval (lane G) results in conversion of the plasmid molecules to linear monomers, $4.4 \mathrm{~kb}$ in size. 


\subsection{Transformants harbouring free plasmid DNA do not contain integrated copies}

Interpretation of the detection of free plasmid molecules in transformants is confounded when a copy or copies of the transforming DNA have also become integrated into the genomic DNA. In such a case, free plasmid may result from a reversal of the integration process, and may not necessarily be maintained by autonomous replication. With this in mind, Southern hybridisation analyses were carried out in order to detect the presence, if any, of integrated sequences in Mucor transformants containing free plasmid molecules.

DNA from transformants R7B-1302-2 and R7B-002-3 was digested with Hpal which cuts within the genomic DNA but not within the transforming plasmids (see section 3.2). Integration should result in the appearance of one or more novel $\mathrm{Hpal}$ fragments but no such bands can be detected in Figure 2, lanes $\mathrm{E}$ and $\mathrm{H}$, where only free plasmid bands and the genomic HpaI fragment of strain R7B can be seen.

Figure 5 shows analysis of the DNA from transformant R7B-006-8. Digestion with PvuII (lane K) which cuts only once within the plasmid pMCL006 enables detection of linear plasmid monomers $(8.8 \mathrm{~kb})$ and one genomic fragment $(11.5 \mathrm{~kb})$ corresponding to the PvuII fragment of the recipient strain R7B (lane E). Integration of the transforming DNA should produce other, novel genomic bands, even if presence of the linear plasmid monomers might be explained by integration of the plasmid as tandem repeats, rather than simply its existence as free plasmid molecules. The absence of any novel Pvull fragments is confirmed when pBR322 is used as hybridisation probe (lane L). Digestion of the DNA with AvaI (lane J) gives patterns allowing the same interpretation since only the $3.9 \mathrm{~kb}$ genomic fragment of strain R7B (lane D) and the $5.9 \mathrm{~kb}$ Aval fragment of pMCL006 are detected. The absence of novel genomic fragments again indicates the absence of integrated sequences.

Analysis of the DNA from transformant R7B4.4P-1 is also shown in Figure 5. PvulI does not cut within the $4.4 \mathrm{~kb}$ PstI fragment used for transformation and lane $\mathrm{H}$ shows only bands corresponding to uncut plasmid DNA (lane F) and the $11.5 \mathrm{~kb}$ genomic PvuII fragment of strain R7B (lane E). AvaI cuts once within the transforming DNA and lane $G$ shows only bands corresponding to linear plasmid monomers $(4.4 \mathrm{~kb}$ ) and the $3.9 \mathrm{~kb}$ genomic Aval fragment of strain R7B (lane D). No novel genomic fragments are seen in either case suggesting the absence of integrated sequences, although in this particular instance homologous integration of the transforming DNA would not be detectable.

\subsection{Mitotic stability of $\mathrm{Leu}^{+}$transformants}

M. circinelloides R7B was transformed to $\mathrm{Leu}^{+}$with pMCL1302 and pMCLO02, and three transformants obtained with each plasmid were transferred to minimal and complete medium and allowed to complete the full vegetative growth cycle culminating in sporangiospore formation. The percentage of viable sporangiospores retaining the $\mathrm{Leu}^{+}$phenotype was estimated by plating sporangiospore suspensions onto complete medium followed by replica plating of colonies onto minimal medium, or by parallel plating of appropriate dilutions onto complete and minimal medium. For pMCL 1302 transformants only 5\% (average for three transformants) of viable sporangiospores were $\mathrm{Leu}^{+}$after the first transfer to complete medium, compared with $45 \%$ when growth was continued under selective conditions. A total of two and three successive transfers to complete medium reduces the percentage $\mathrm{Leu}^{+}$to $0.8 \%$ and $0.056 \%$, respectively. The results obtained with pMCLO02 transformants were similar: $13 \% \mathrm{Leu}^{+}$after one transfer to complete medium (compared with $44 \%$ Lea $^{+}$after growth on minimal medium) which decreased to $1.7 \%$, then $0.162 \%$ after the second, and third transfer to complete medium. The mitotic stability of the Leu ${ }^{+}$phenotype is comparable to that observed for autonomously replicating plasmids in transformants of $S$. cerevisiae $(17,18)$. It is much lower than that expected if an integrated copy/ copies of the transforming DNA were to be present since in other fungi integrative transformants are found to be almost, if not completely, mitotically stable, even after growth under nonselective conditions (e.g. 6, 11, 17, 21, 40). 


\section{DISCUSSION}

The results presented here demonstrate that plasmids pMCL1 302 and pMCL002 are present as extrachromosomal DNA molecules within $\mathrm{Leu}^{+}$transformants of Mucor circinelloides. These plasmids exhibit all the features of autonomously replicating plasmid molecules, as defined by studies in the yeast $\mathrm{S}$. cerevisiae (12, 17,39): (i) they give a high frequency of transformation, (ii) they are not stably maintained during mitosis, (iii) they can be reisolated in an unmodified form from uncut transformant DNA, and,(iv) their presence as discrete DNA molecules can be detected in transformant DNA, in this case by Southern hybridisation to radioactive probes. These properties suggest that plasmids pMCL1 302 and pMCL002 carry an ars sequence(s) capable of functioning in Mucor.

Requirement of the $A R S$ or $O R I$ regions of vectors YRp17 and pBR322 for autonomous replication of plasmids in Mucor is excluded by the maintenance of pMCLO02 or the $12.2 \mathrm{~kb}$ Bgll fragment derived therefrom as free plasmid molecules in their respective transformants. Further evidence that these or other vector sequences are not essential comes from the $\mathrm{Leu}^{+}$ transformants obtained with the self-ligated 4.4 kb PstI fragment of Mucor DNA alone. These transformants contain discrete extrachromosomal DNA molecules and are mitotically unstable under non-selective conditions (results not shown) suggesting that the $4.4 \mathrm{~kb}$ PstI fragment contains not only the $\mathrm{Leu}^{+}$gene but also a Mucor ars sequence. Plasmid pMCL006, consisting of this fragment cloned into the PstI site of $p B R 322$, transforms $M$. circinelloides $\mathrm{R} 7 \mathrm{~B}$ to $\mathrm{Leu}^{+}$at a high frequency $(2700$ per $\mu \mathrm{g}$ DNA) whereas plasmid pMCL005 consisting of the $3.9 \mathrm{~kb}$ Aval fragment of pMCL1 302 inserted into the Aval site of pBR322 transforms strain R7B at only a very low frequency, or not at all. Only one $\mathrm{Leu}^{+}$colony has been obtained from two independent transformation experiments using up to $20 \mu \mathrm{g}$ pMCL005 per transformation.

Reports exist of autonomously replicating plasmids in P. anserina (36) and N. crassa (14, $22,26,38$ ) although no precise localisation of the DNA sequences responsible for autonomous replication have yet been made. In N. crassa the frequent rearrangements, insertions and dele- tions within the transforming plasmids suggests they are unstable within this organism and complicates the analysis of transformant DNA. Those transformants shown to contain free plasmid generally also contain plasmid sequences integrated in the chromosomal DNA. This can make it difficult to distinguish whether the free plasmid molecules detected are excision products derived from a reversal of the integration process, or whether they really are maintained by a process of autonomous replication. Evidence for the excision of integrated plasmids or derivatives thereof has been found in transformants of S. cerevisiae (39) and A. nidulans (4, 20 ). In the case of Mucor circinelloides as described herein, no integrated sequences could be detected in the Leu ${ }^{+}$transformants shown to contain free plasmid DNA. This excludes the possibility that an excision process is responsible for the presence of discrete plasmid molecules and hence the latter must be maintained by a process of autonomous replication.

The isolation of a DNA fragment carrying an ars sequence functioning in Mucor facilitates the genetic analysis and manipulation of this organism. It enables the construction of shuttle vectors which transform Mucor at high frequencies and which can be reisolated unmodified from the transformant DNA. The preparation of genomic libraries in such vectors should make the cloning of Mucor genes by direct complementation a rapid and straightforward procedure. The ability to maintain the transforming DNA as an extrachromosomal element should also enable studies on expression and regulation of homologous and heterologous genes in $\mathrm{Mu}$ cor to be carried out without the complications arising from single or multiple integration events within the genome.

\section{ACKNOWLEDGEMENTS}

I would like to thank STEEN HOLMBERG for his advice throughout the course of this work and for critically reading the manuscript, PETER B. Høנ for performing the Southern hybridisation analyses for Figure 5, ANETTE JøRGENSEN and MONA ELSTER for technical assistence, and NINA RASMUSSEN and ANN-Sofi STEINHOLTZ for preparation of the figures. 


\section{REFERENCES}

1. AdAMS, P. R. \& J. J. Deploey: Amylase production by Mucor miehei and Mucor pusillus. Mycologia 68, 934-938 (1976)

2. Arima, K, S. IwASAKI \& G. Tamura: Milk-clotting enzyme from microorganisms. V. Purification and crystallization of Mucor rennin from Mucor pusillus var. Lindt. Appl. Microbiol. 16, 1727-1733 (1968)

3. Ballance, D. J., F.P. Buxton \& G. TuRner: Transformation of Aspergillus nidulans by the orotidine-5'-phosphate decarboxylase gene of Neurospora crassa. Biochem. Biophys. Res. Commun. 112, 284-289 (1983)

4. Ballance, D. J. \& G. Turner: Development of a high frequency transforming vector for Aspergillus nidulans. Gene 36, 321-331 (1985)

5. BARTNICKI-GARCIA, S: Symposium on biochemical bases of morphogenesis in fungi. III. Moldyeast dimorphism of Mucor. Bacteriol. Rev. 27, 293-304 (1963)

6. Begueret, J., V. RaZanamparany, M. Perrot \& C. BARREAU: Cloning gene ura5 for the orotodylic acid pyrophosphorylase of the filamentous fungus Podospera anserina: transformation of protoplasts. Gene 32, 487-492 (1984)

7. BRygoo, Y. \& R. Debuchy: Transformation by integration in Podospora anserina. I. Methodology and phenomenology. Mol. Gen. Genet. 200, 128131 (1985)

8. BUXTON, F. P.\& A. RADFORD: The transformation of mycelial spheroplasts of Neurospora crassa and the attempted isolation of an autonomous replicator. Mol. Gen. Genet. 196, 339-344 (1984)

9. Buxton, F. P., D. I.GWynne \& R. W. Davies: Transformation of Aspergillus niger using the argB gene of Aspergillus nidulans. Gene 37, 207-214 (1985)

10. CASE, M. E.: Transformation of Neurospora crassa utilising recombinant plasmid DNA. In: Genetic engineering of microorganisms for chemicals. A. Hollaender, R. D. DeMoss, S. Kaplan, J. Konisky, D. Savage and R. S. Wolfe, eds., Plenum Press. N. Y., pp. 87-100 (1982)

11. Case, M. E., M. Schweizer, S. R. Kushner \& N. H. Giles: Efficient transformation of Neurospora crassa by utilizing hybrid plasmid DNA. Proc. Natl. Acad. Sci. USA. 76, 5259-5263 (1979)

12. Chan, C. S. M. \& B. -K. TYE: Autonomously replicating sequences in Saccharomyces cerevisiae. Proc. Natl. Acad. Sci. USA 77, 6329-6333 (1980)

13. Gauger, W: The germination of zygospores of Mucor hiemalis. Mycologia 57, 634-641 (1965)

14. Grant, D. M., A. M. Lambowitz, J. A. RamboseK \& J. A. KINSEY: Transformation of $\mathrm{N}$. crassa with recombinant plasmids containing the cloned glu- tamate dehydrogenase (am) gene: evidence for autonomous replication of the transforming plasmid. Mol. Cell. Biol. 4, 2041-2051 (1984)

15. HeEswiJCK, R. vAN: The formation of protoplasts from Mucor species. Carlsberg Res. Commun. 49, 597-609 (1984)

16. HeEswiJCK, R. vaN \& M. I. G. RONCERo: High frequency transformation of Mucor with recombinant plasmid DNA. Carlsberg Res. Commun. 49 , 691-702 (1984)

17. Hicks, J. B., A. Hinnen \& G. R. Fink: Properties of yeast transformation. Cold Spring Harbor. Symp. Quant. Biol. 43, 1305-1313 (1979)

18. Hyman, B. C., J. H. Cramer \& R. H. Rownd: Properties of a Saccharomyces cerevisiae mtDNA segment conferring high-frequency yeast transformation Proc. Natl. Acad. Sci. USA 79, 1578-1582 (1982)

19. IsH-Horowicz, D. \& J. F. Burke: Rapid and efficient cosmid cloning. Nucl. Acid. Res. 9, $2989-$ 2998 (1981)

20. Johnstone, I. L., S. G. Hughes \& A. J. ClutterBUCK: Cloning an Aspergillus nidulans developmental gene by transformation. EMBO J. 4, 1307 $1311(1985)$

21. KELlY, J. M. \& M. J. HYNES: Transformation of Aspergillus niger by the amdS gene of Aspergillus nidulans. EMBO J. 4, 475-479 (1985)

22. KUIPER, M. T. R. \& H. DE VRIES: A recombinant plasmid carrying the mitochondrial plasmid sequence of Neurospora intermedia LaBelle yields new plasmid derivatives in Neurospora crassa transformants. Curr. Genet. 9, 471-477 (1985)

23. MANDEL, M.\&A. HiGA: Calcium-dependent bacteriophage DNA infection. J. Mol. Biol. 53, 159-162 (1970)

24. Maniatis, T., E. F. Fritsch \& J.SAMbrook: Molecular cloning, a laboratory manual. Cold Spring Harbor, New York (1982)

25. OTTESEN, M. \& W. RiCKerT: The isolation and partial characterisation of an acid protease produced by Mucor miehei. Compt. Rend. Trav. Lab. Carlsberg 37, 301-325 (1970)

26. PaietTa, J. \& G. A. Marzluf: Plasmid recovery from transformants and the isolation of chromosomal DNA segments improving plasmid replication in Neurospora crassa. Curr. Genet. 9, 383-388 (1985)

27. RAO, T. R \& C. A. REDDY: DNA sequences from a ligninolytic filamentous fungus Phanerochaete chryosporium capable of autonomous replication in in yeast. Biochem. Biophys. Res. Commun. 118, 821-827 (1984)

28. Rigby, P. W. J., M. DieckmanN, C. Rhodes \& P. BERG: Labeling deoxyribonucleic acid to high 
specific activity in vitro by nick translation with DNA polymerase I. J. Mol. Biol. 113, 237-251 (1977)

29. RONCERO, M. I. G.: Enrichment method for the isolation of auxotrophic mutants of Mucor using the polyene antibiotic N-glycosyl-polifungin. Carlsberg Res. Commun. 49, 685-690 (1984)

30. SCHIPPER, M. A. A.: On Mucor circinelloides, Mucor racemosus and related species. Studies in Mycology 12, 1-40 (1976)

31. SCHIPPER, M. A. A.: On certain species of Mucor with a key to all accepted species. Studies in Mycology 17, 1-52 (1978)

32. SKatRud P. L. \& S. W. QueEner: Cloning of a DNA fragment from Cephalosporium acremonium which functions as an autonomous replication sequence in yeast. Curr. Genet. 8, 155-163 (1984)

33. SomkUTl, G. A.: Synthesis of cellulase by Mucor pusillus and Mucor miehei. J. Gen. Microbiol. 81, 1-6 (1974)

34. Somkutı, G. A. \& F. J. Babel: Lipase activity of Mucor pusillus. Appl. Microbiol. 16, 617-619 (1968)

35. SOUTHERN, E. M.: Detection of specific sequences among DNA fragments separated by gel electrophoresis. J. Mol. Biol. 98, 503-517 (1975)

36. Stahl, U., P. TUdzynski, U. KuCK \& K. EsSER: Replication and expression of a bacterial-mitochondrial hybrid plasmid in the fungus Podospora anserina. Proc. Natl. Acad. Sci. USA. 79, 3641 3645 (1982)

Accepted by E. LunD
37. Stinchomb, D. T., M. Thomas, J. Kelly, E. Selker \& R. W. DAVIS: Eukaryotic DNA segments capable of autonomous replication in yeast. Proc. Natl. Acad. Sci. USA 77, 4559-4563 (1980)

38. STOHL, L. L. \& A. M. LAmbowitz: Construction of a shuttle vector for the filamentous fungus Neurospora crassa. Proc. Natl. Acad. Sci. USA. 10581062 (1983)

39. Struhl, K., D. T. Stinch Comb, S. SCherer \& R. W. DAVIS: High frequency transformation of yeast: Autonomous replication of hybrid DNA molecules. Proc. Nat. Acad. Sci. USA 76, 10351039 (1979)

40. Tilburn, J., C. Scazzocchio, G. G. Taylor, J. H. Zabicky-Zissman, R. A. LoCKINGTON \& R. W. DAVIES: Transformation by integration in Aspergillus nidulans. Gene 26, 205-221 (1983)

41. TUDZYNSKI, P. \& K. ESSER: Extrachromosomal genetics of Cephalosporium acremonium II. Development of a mitochondrial DNA hybrid vector replicating in Saccharomyces cerevisiae. Curr. Genet. 6, 153-158 (1982)

42. Turgeon, B. G., R. C. Garber \& O. C. Yoder: Transformation of the fungal maize pathogen Cochliobolus heterostrophus using the Aspergillus nidulans amdS gene. Mol. Gen. Genet. 201, 450453 (1985)

43. Yelton, M. M., J. E. Hamer \& W. E. Timberlake: Transformation of Aspergillus nidulans by using a trpC plasmid. Proc. Natl. Acad. Sci. USA 84, 1470-1474 (1984) 